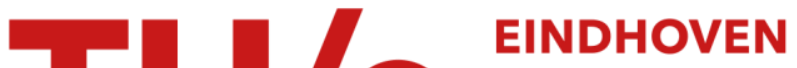 \\ UNIVERSITY OF \\ TECHNOLOGY
}

\section{Biomass energy policies and strategies : harvesting potential in India and Indonesia}

Citation for published version (APA):

Singh, R., \& Setiawan, A. D. (2013). Biomass energy policies and strategies : harvesting potential in India and Indonesia. Renewable and Sustainable Energy Reviews, 22, 332-345. https://doi.org/10.1016/j.rser.2013.01.043

DOI:

10.1016/j.rser.2013.01.043

Document status and date:

Published: 01/01/2013

\section{Document Version:}

Publisher's PDF, also known as Version of Record (includes final page, issue and volume numbers)

\section{Please check the document version of this publication:}

- A submitted manuscript is the version of the article upon submission and before peer-review. There can be important differences between the submitted version and the official published version of record. People interested in the research are advised to contact the author for the final version of the publication, or visit the $\mathrm{DOI}$ to the publisher's website.

- The final author version and the galley proof are versions of the publication after peer review.

- The final published version features the final layout of the paper including the volume, issue and page numbers.

Link to publication

\section{General rights}

Copyright and moral rights for the publications made accessible in the public portal are retained by the authors and/or other copyright owners and it is a condition of accessing publications that users recognise and abide by the legal requirements associated with these rights.

- Users may download and print one copy of any publication from the public portal for the purpose of private study or research.

- You may not further distribute the material or use it for any profit-making activity or commercial gain

- You may freely distribute the URL identifying the publication in the public portal.

If the publication is distributed under the terms of Article 25fa of the Dutch Copyright Act, indicated by the "Taverne" license above, please follow below link for the End User Agreement:

www.tue.nl/taverne

Take down policy

If you believe that this document breaches copyright please contact us at:

openaccess@tue.nl

providing details and we will investigate your claim. 


\title{
Biomass energy policies and strategies: Harvesting potential in India and Indonesia
}

\author{
Rajbeer Singh*, Andri D. Setiawan \\ Technology Dynamics and Sustainable Development, Department of Values and Technology, Faculty of Technology, Policy, and Management, \\ Delft University of Technology, Jaffalaan 5, 2628BX Delft, The Netherlands
}

\section{A R T I C L E I N F O}

\section{Article history:}

Received 15 March 2012

Received in revised form

22 January 2013

Accepted 23 January 2013

Available online 15 March 2013

\section{Keywords:}

Biomass energy

India

Indonesia

Policy

Strategy

Sustainability

\begin{abstract}
A B S T R A C T
India and Indonesia are privileged with abundant biomass resource potentials, 23 Giga-watt (GW) and $50 \mathrm{GW}$ equivalents respectively, yet both countries harvest small proportions, with fundamentally different deployed policies and articulated strategies. In this regard, this paper focuses on analyzing evolution and deployment of different policies and execution of strategies by two countries. It analyzes the effects of the biomass energy policies and executed strategies in India and Indonesia with a holistic approach. Such an approach takes the policy and strategy of the whole biomass energy sector rather than a segmented and separated sector as biofuel, biogas, biodiesel, etc. Furthermore, how they have resulted in different outcomes is also addressed. Our analysis shows that India's biomass energy policy has evolved from incremental to more radical changes, while Indonesia's policy remains incremental. India has also a relatively more unified biomass energy strategy than Indonesia. India has been more focused on technology development and deployment along with strong institutional creation, whereas Indonesia has not been able to create any biomass sector supporting strong institutions. Therefore, in terms of biomass energy utilizations, India has demonstrated better performance than Indonesia.
\end{abstract}

(c) 2013 Elsevier Ltd. All rights reserved.

\section{Contents}

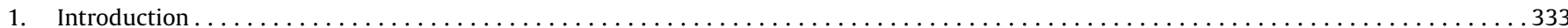

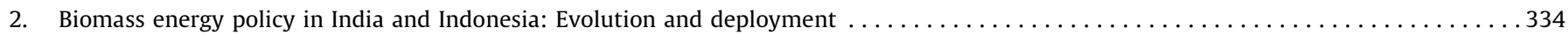

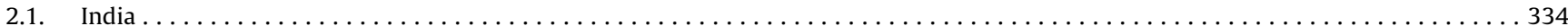

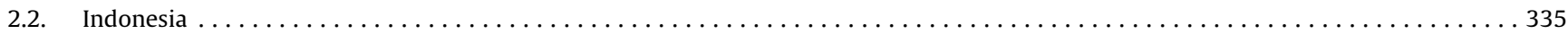

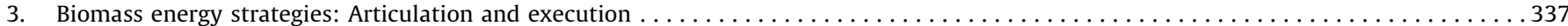

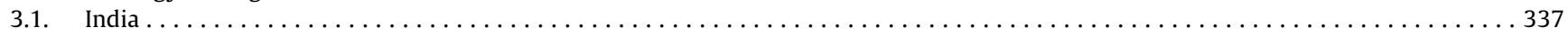

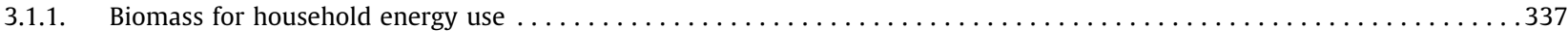

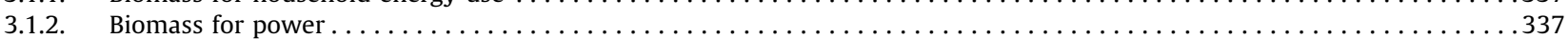

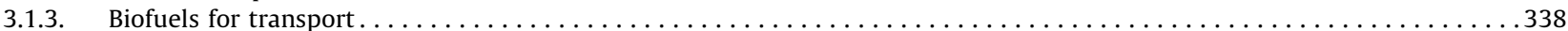

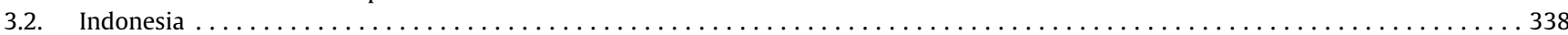

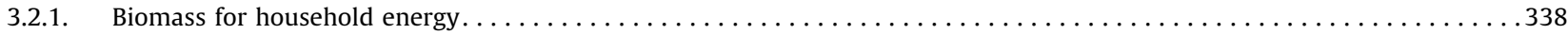

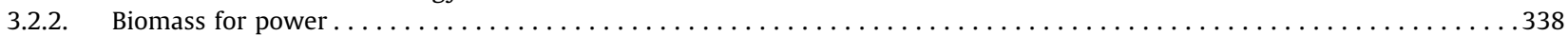

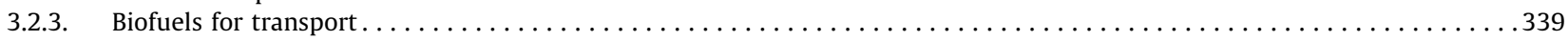

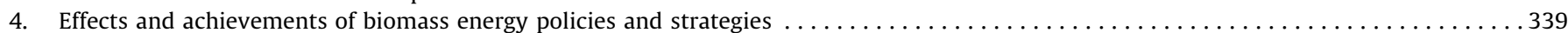

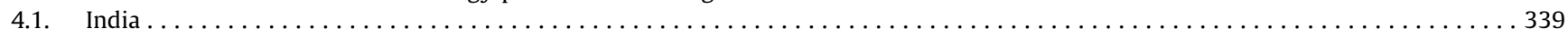

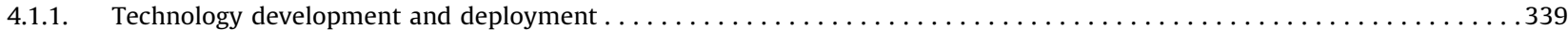

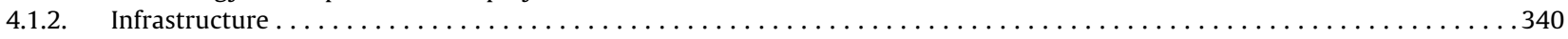

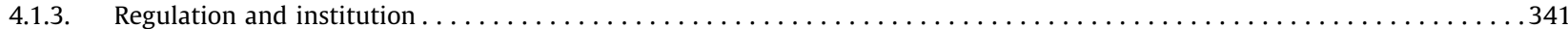

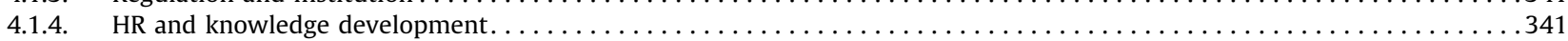

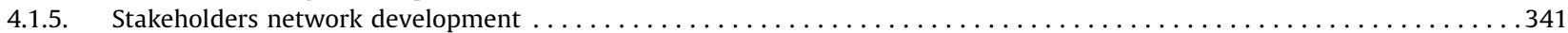

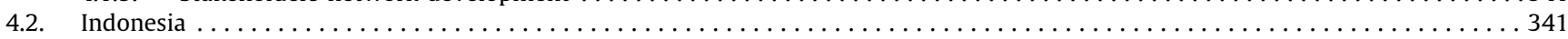

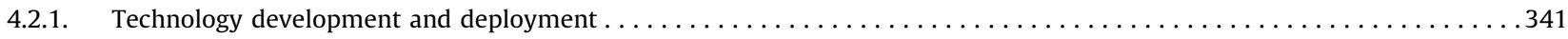

\footnotetext{
* Corresponding author. Tel.: +31 633202 237, +31 15278 6485; fax: +31 152783177.

E-mail addresses: rajbasera@gmail.com (R. Singh), andrids@yahoo.com (A.D. Setiawan).
} 


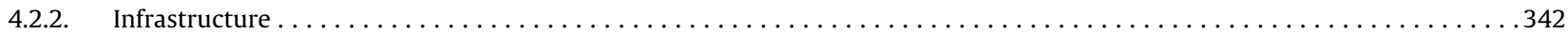

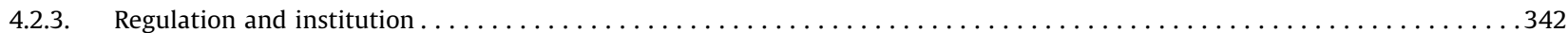

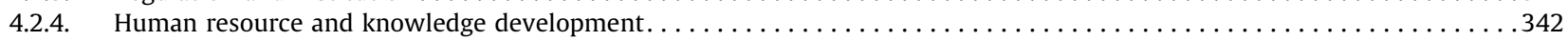

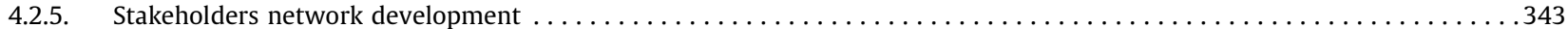

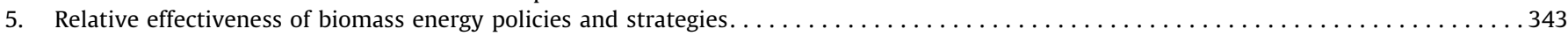

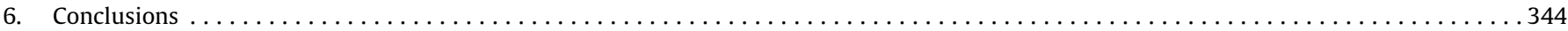

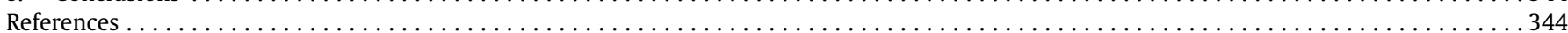

\section{Introduction}

India and Indonesia (besides China) are the most populated developing countries, with relatively high economic growth. Despite the global economic turndown since 2009, the gross domestic product (GDP) annual growth rates in India and Indonesia were $6.90 \%$ [1] and 6.50\% [2] respectively in 2011. This growth is very high in comparison to other world economies. Hence, the energy consumption of both countries also increased significantly. It reached 669 million tonnes of oil equivalent (Mtoe) and 214 Mtoe in India and Indonesia, respectively. Since 2005 , energy consumptions in the respective countries have been growing at rates of $4.92 \%$ and $3.93 \%$ per year[3]. The primary usage of energy in India and Indonesia is still dominated by fossil fuels. India's primary energy consumption in 2009 was mainly shared by coal, $42 \%$, oil, $23 \%$, and natural gas, $7 \%$ [3]. Similarly, in Indonesia, the total energy was proportionately supplied by oil, $32 \%$, coal, $19 \%$ and natural gas, $18 \%$, in the same year [3]. Moreover, in the near future, the rising demand for energy due to economic growth has to be matched with additional sources of energy. But, in absence of any additional sources, such additional demands could be matched by increased supply of coal in both the countries. However, India's domestic production of coal cannot cope with its increasing energy demand. Therefore, India needs to import coal [4] and acquire coal reserves in different countries. Meanwhile, having sizable coal resources, Indonesia under its policy would increase usage of coal up to $33 \%$ of its total energy mix by 2020 [5]. Inevitably, the increased use of coal in both countries will lead to higher green-house gas (GHG) emissions and increase other environmental problems. Therefore, this indicates for exploring other energy resources like renewable energy (biomass and solar) for tackling the above challenges.

India and Indonesia are endowed with abundant biomass resources for increasing additional energy supply. The biomass energy contributes about one-third of their total energy consumption. It was $26 \%$ and $27 \%$ in India and Indonesia respectively in 2010 [3]. Biomass is a vital energy source for rural households for cooking and heating in India. It is also the most common energy source used by several small-scale industries and independent power plants. The estimates show that 120-150 million metric tons of biomass per year is generated in India by agricultural and forestry residues, which is equivalent to a potential of about 18 Giga-watts (GW) [6]. In addition to this, around 550 sugar mills could also generate about $5 \mathrm{GW}$ additional power [6]. Similarly, most biomass energy in Indonesia is also utilized in households, agriculture, wood and sugar industries, in rural area for cooking, lighting, rice milling, drying agri-produce, and heat and power generation. The Indonesian biomass potential is estimated as equivalent to $50 \mathrm{GW}$. It consists of 15.45 million cubic meters of forest residues per year, 64 million tons of plantation residues per year, $144.50 \mathrm{t}$ agricultural residue per year, and $11,330 \mathrm{t}$ municipal waste per day [7]. However, it remains under-tapped and underutilized.

Despite the huge potential of biomass in both countries, its utilizations are still in traditional ways (e.g. cooking and lighting in rural areas). The technologies used are not efficient and environmental friendly. There is also less innovation in its utilization. It shows that biomass is not used in a sustainable way. Therefore, approach of sustainability is missing. For instance, in terms of power generation, biomass is less utilized for supplying electricity for rural households than what is used by sugar and oil palm plantations, and small and medium enterprises. Therefore, power supply from biomass to rural households is a major challenge for government policies and strategies.

In the meantime, the governments of both countries have encouraged policies and executed strategies for the utilization of renewables for energy supply (i.e., biomass) in order to reduce reliance on fossil fuels in the long term, improve efficiency, and reduce GHG emissions. Consequently, it creates sustainability in the energy sector. This needs to be explored since research is lacking on the above aspects of biomass energy issues up to some extent.

So far, literature on biomass energy reflects that research on biomass energy in India and Indonesia have been focused mainly on its utilization for households, small-industries, plantations, small-distributed power generation, and transport separately. Such compartmentalized researches address aspects on biomass energy conversion technology and production like biomass gasification [8-10], biofuel [11], biodiesel [12], and biomass cogeneration [13]. Few researches touch upon the policy context, e.g. prospects, barriers, and policy option of biomass [14-16]. However, research focusing on the effects of the policy and strategy regarding biomass energy with a holistic approach in both countries is missing. The analytical framework here takes the policy and strategy aspects in holistic approach as a whole sector of biomass energy rather than a segmented and separated approach as biodiesel, biofuel, biogas, etc.

Therefore, this review paper focuses on biomass energy policies and strategies in India and Indonesia, in particular by addressing the following issues with a holistic approach: (1) How the potentials of biomass energy resources in both countries are harvested; (2) what are the achievements of deployed policies, and how the strategies were articulated and executed for attaining policy objectives in both countries and (3) which policies and strategies are relatively more effective between the two countries? By addressing these questions, this paper attempts to create an understanding about policy deployment and strategy articulation and their effects in two important developing countries. Although the main focus of the paper is on India and Indonesia, it would be relevant to other developing countries which would be looking to further develop their biomass energy resources.

The paper is organized as follows: Section 2 reviews biomass energy policies deployed by India and Indonesia for the development of biomass energy resources. Section 3 reviews different adopted and deployed strategies in both countries. Section 4 discusses the effects and the achievements of policies and strategies in both countries in the biomass energy sector. Section 5 discusses the relative effectiveness of the policies and strategies in the two countries for harvesting the potential of biomass energy. And finally, Section 6 concludes, with possible scope for future research. 


\section{Biomass energy policy in India and Indonesia: Evolution and deployment}

This section focuses on bioenergy policy evolution and deployment in India and Indonesia. It elucidates how the governments of both countries developed the policies, their objectives, and how such policies have been deployed.

\subsection{India}

The renewable energy policies in India, including biomass energy, were initially developed and brought in place in response to the oil crisis during the 1970s. The first global energy crisis led to the decision and conclusion among policy makers to set up some policy and working group to deal with energy issues. Therefore, as a first step, in the year 1974, the Fuel Policy Committee (FPC) was established by the Government of India. This was followed by another step in 1979 through setting up a Working Group on Energy Policy (WGEP). Both initiatives were oriented to shield and prepare the energy market for long term future unseen and unexpected energy shocks. With such an approach, the WGEP expected to develop a solid plan and recommendations for policy measures regarding conventional and non-conventional energy resources for 5-15 years ahead [17].

This policy evolution process turned into some more sequential actions for creating institutions and organizations which could actively shape and develop the policies and policy processes. One of such outcomes was the establishment of the Commission for Additional Sources of Energy (CASE) in 1981. The CASE got enhanced responsibilities and mandate in the form of policy implementation or deployment. In addition, it was entrusted tasks like research and development, and induction of renewable energy technologies in different sectors. Therefore, CASE became a face of policy evolution and deployment. In 1982, CASE was turned into the Department of Non-Conventional Energy Sources (DNES), a new department under the Ministry of Energy. DNES was entrusted to promote non-conventional energy sources in India [17].

The bioenergy policy in India during the 1980s focused on different scales of technology, from small to large. Each scale had different orientation, from micro to macro levels. In the small scale and micro level, the major focus of the policy was to improve efficiency and quality of the traditional usage of biomass, e.g. improved cooking stove programs and biogas. This approach was focused on addressing supply side issues by increasing the supply and usage of biomass. Some such examples are social forestry and forestation of local wasteland. On the medium-to-large scale, large and macro level, the policy was mainly focused on biomass gasification technology, e.g. wood gasifiers. It was focused on delivering services provided by conventional energy sources and electricity generation at medium and large scales.

The policy was evolved in the early 1990s, so far, to create institutional support for program formulation and implementation at macro as well as micro levels, with incremental change. However, such a piecemeal policy approach was changed to a leapfrogging approach with a decision in the year 1992. In this year was witnessed a parallel step of upgradation of DNES as a ministry, namely, the Ministry of Non-Conventional Energy Sources (MNES). This radical step was aimed at expansion and exploration of the scope for renewable energy promotion activities in India. At this point of policy evolution, the policy formulation and deployment responses proved to be highly ambitious and assertive for capturing renewable energy resources by providing more financial and institutional support. The sole responsibility for supporting research and development, and promoting and coordinating renewable energy sources, including biomass energy [17], was ensured with the newly formed ministry. Therefore, so far, the analysis suggests that the policy was actually evolved from incremental to radical orientation in terms of institutional setup. This process got further acceleration in the year 2006 when MNES was reformed as the Ministry of New and Renewable Energy (MNRE). MNRE became the highest institution in the new and renewable energy sector and got responsibility of developing policy and deploying strategy in such sectors, including biomass energy. This policy approach paved the way for MNRE to furnish a strong institutional role in the sector for harnessing biomass energy sources as well. In addition, the State Nodal Department/Agency (SNA) was assigned as an authorized agency of MNRE, with the main task to monitor and implement the policy at the state level in each state. Further, such a task was carried out in cooperation with local government bodies at the local level.

Policy articulation has created more conducive context and situation through enabling paths to set up more institutions and new laws (e.g. related to electricity, efficiency, etc.). This can be witnessed by the example of creation of the Indian Renewable Energy Development (IREDA) as a Non-Banking Financial Institution under the administrative control of MNRE. This paved the way for the biomass sector along with the other renewables sectors to get strong institutional support in terms of finance. This institutionalization process further laid down the foundation of the Bureau of Energy Efficiency (BEE) through the Energy Conservation Bill passed by the Indian Parliament in 2001. This law was meant for providing a legal framework, regulatory mechanisms and institutional arrangements at the central and state government to foster energy efficiently in the country. This step constitutes the essential part in laying the foundation of the future energy policy formulation of the country. The formulated policy in the 11th five-year plan (2007-2012) highlighted several energy issues such as shortages of energy, the dominance of coal as an energy source, the need of expanding resources through exploration, energy efficiency, utilization of renewables, and research and development in energy [18].

The large policy initiative, the National Action Plan on Climate Change, with macro level focus, was launched during June, 2008, in response to the global concerns for addressing climate change. It was manifested into eight national missions comprising the main response for addressing climate change: Solar Energy, Enhanced Energy Efficiency, Sustainable Habitat, Water, Sustaining the Himalayan Ecosystem, Green India, Sustainable Agriculture, and Strategic Knowledge for Climate Change [19]. Another stage of policy evolution totally focused on biomass energy was of putting up a new National Policy on Biofuel in 2008. This policy included the use of biomass energy resources with the deployment of better technology by considering sustainability as the main task. Additionally, it was also envisaged to develop next generation technologies and the framework for strategic interventions. Table 1 depicts evolutionary processes and reflects the deployment of some policies on biomass energy resources in India during 2000-2010.

Currently, the Government of India is relatively ambitious on policy making, regulation, institutional creation, and mobilization of industry interest into biomass; e.g., by liberal tax regime, easy land acquisition, and compulsory power purchasing from biomass based power producers. However, what is experienced by and occurring in India might not be the same with other developing countries. Therefore, to see any differences and how such policies evolved and deployed in other developing countries would be very important. Such experiences are considered for another country from Asia. In Section 2.2 we will look into the evolution and deployment of biomass energy policy in Indonesia, which also has huge biomass potential. 
Table 1

Evolution of policies related to biomass energy in India during 2000-2010.

Source: [20].

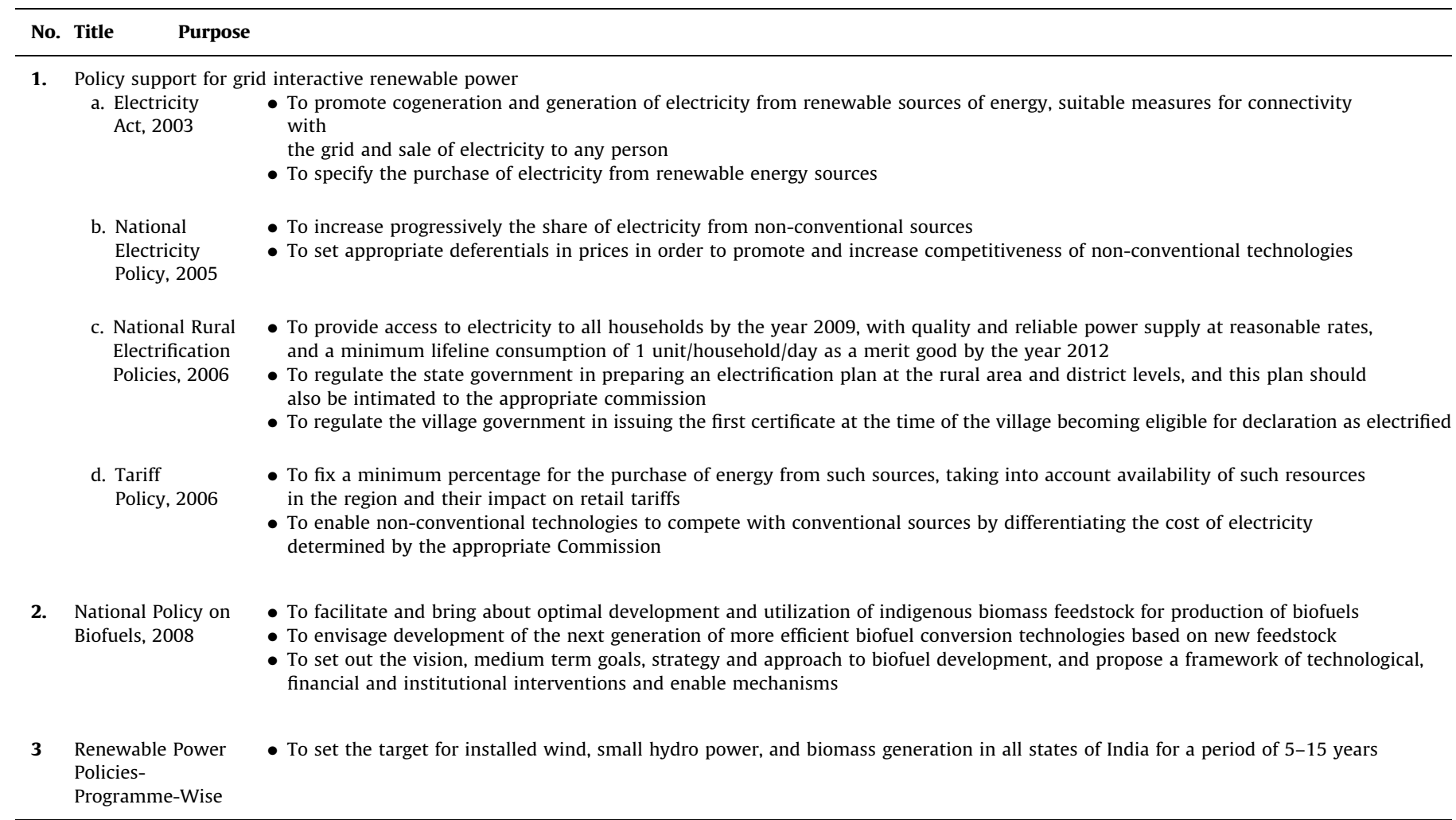

\subsection{Indonesia}

The first global oil shock had convinced policy makers in Indonesia to take initiatives to address the existing as well as future energy supply related challenges. Forced by the additional oil shock in the early 1980s, Indonesia launched its first energy policy under Presidential Instruction no. 9/1982, with its main focus on energy conservation. The first policy was based on two principal approaches; the first is the incremental or piecemeal approach, and the second is the conservation approach. Under such approaches, the scope of policy was focused on directing all government ministries and agencies and state owned enterprises to undertake energy conservation measures.

The above policy evolution process got further push when a new Ministerial Energy Coordination Board (Bakoren) was established. In the chairmanship of the Minister of Mines and Energy, Bakoren was assigned tasks to issue general policy guidelines on energy matters. It means, so far, there was a generalized orientation of policy process. Furthermore, this institution got another committee in the early 1990s with the name of the National Committee on Energy Conservation (NCEC). The NCEC had paved the way for institutionalization in the energy sector. The NCEC had provided more support to the government at the macro level in terms of formulation of laws, regulations, and guidelines related to energy policy. At the micro level, the committee formulated implementation campaigns and took other actions to promote the energy efficiency program.

After spending one decade on incremental evolution on energy policy, the environmental aspects entered into the policy formulation process. The Presidential Decree no. 43/1991, about Energy Conservation with greater attention on energy efficiency and environmental sustainability, was enacted as the next level of policy. At this stage, there were great efforts and emphases to give more attention to renewable energy sources like biomass. Compared to energy policy in the 1980s, the policy in the 1990s had broader scope of implementation. It shows that the policy during the 1980s and 1990s evolved from micro level to macro level orientation, with incremental change.

Furthermore, after year 2000 when the Ministry of Mines and Energy was reformed as the Ministry of Energy and Mineral Resource (ESDM), the energy sector in Indonesia has been dominated by four policy objectives, as follows [5,21]:

1. Energy diversification,

2. Rational energy pricing,

3. Energy sector reform, and

4. Rural electrification.

Under the above policy objectives, the energy policy in Indonesia has been focusing on both supply and demand sides. On the supply side, the policy focused on energy conservation and intensification, reducing oil dependence, increasing energy supply from non-renewable (coal and gas) and renewable sources, electrification of rural areas(90\% population by 2020), better appropriation of subsidies and attracting more investment by creating favorable conditions. While on the demand side, the focus consisted of better pricing mechanisms, more focused and reduced subsidies with better out comes, stimulating competitiveness among different energy sources based on principles of diversification and energy efficiency. The vision of the policy is to guarantee the sustainable energy supply to support national development. At the macro level, the policy has been oriented to create a better regulatory and institutional system by enacting several laws and regulations. In this way, the utilization and development of renewable energy sources also got better attention and support from the government. The policy was also aimed at bringing reforms at institutional, financial, governance and 
industrial levels, with the aim to bring about transparency and inclusion for planning and implementation. In this regard, ESDM is responsible for monitoring and implementing the policy at the national level. Such responsibility is also carried out by the ESDM Provincial Agency at the province level, and the ESDM Local Agency at the local level.

Biomass energy policy in Indonesia basically follows Presidential Regulation no. 5/2006 on National Energy Policy as the basis for biomass energy development. It set the targets for an optimal energy mix in 2025, where renewables contribute more than $15 \%$ of the total energy mix. It has $5 \%$ biofuel, $5 \%$ other renewable, including other type of biomass energy, nuclear, micro-hydro, solar, and wind, and 5\% geothermal [22] energy. Thus, biomass energy is expected to contribute about $5-10 \%$ of the total energy mix in 2025. The policy gave more emphasis on the utilization of biofuel. This was after Presidential Instruction (Inpres) no. 1/2006 on the supply and use of biofuel was issued. At the micro level, this aimed at creating pro-job biofuel projects and encouraging local development. At the macro level, focus was on development of multi-sectoral coordination among ministries for biofuel development. Furthermore, the evolutionary process and deployment of some policies related to renewable energy as well as biomass energy in Indonesia during 2000-2010 are depicted in Table 2.
Table 2 also reflects that the policy in general is more oriented to the macro level for the utilization of biomass energy and its technology for power generation and transportation sector. Less attention is given to the utilization of biomass at the small scale and micro level sector, e.g. for households. Moreover, the policy evolution process is less radical in its approach for bringing up changes and creating institutions for biomass energy as part of renewable energy sector. However, there were efforts to make changes faster through creating another institution, the Directorate of New and Renewable Energy and Energy Conservation (EBTKE) under ESDM in 2010. The main task of EBTKE is to formulate and implement policies and regulations regarding new and renewable energy and energy conservation [5]. This way, the biomass energy sector, along with other renewable energy sources, is expected to get more institutional and policy support for regulation and implementation.

The evolution and deployment of the policies related to biomass energy in India and Indonesia, as elucidated in Sections 2.1 and 2.2, have given opportunities for both countries in order to develop and use strategies for harvesting biomass energy potential in each country. But what kind of strategies have been adopted and executed by the respective countries are covered in the next section.

Table 2

Evolution of policies related to biomass energy in Indonesia during 2000-2010. Source: [21].

$\begin{array}{ll}\text { No. Title Purpose } & \text { Pure }\end{array}$

1. Ministerial Decree no. 1122 on Small-Scale Distributed Renewable Power Plant, 2002

2. Ministerial Decree no. 02 on Green Energy Policy, 2004

3. Government Rule no. 3 on Supply of Electricity, 2005

4. Blueprint of National Energy Implementation Program 2005-2025 issued by Minister of Energy and Mineral Resources, 2005

5. Presidential Regulation no. 5 on National Energy Policy, 2006

6. Presidential Decree no. 1 on Supply and Use of Biofuel, 2006

7. Ministerial Regulation no. 2 on Medium Scale Power Generation from Renewable Energy Sources, 2006

8. Energy Law (Law no. 30/2007):

9. Electricity Law (Law no. 30/2010):

\section{Purpose}

- To give incentive on the development of renewable energy for small-scale distributed power plants which require PLN (State Electricity Company) to purchase electricity generated from renewable energy sources by non-PLN producers for projects of up to 1 MW capacity

- To optimize the utilization of renewable energy

- To utilize energy technology efficiently, both from renewable and non-renewable energy.

- To increase public awareness in energy efficiency

- To supports Law no. 15/1985 on electricity, which was reenacted in late 2005 following a Constitutional Court ruling that annulled Law no. 20/2002 on electricity

- To regulate the partnership between independent power producers (IPPs) partnered with PLN to develop electricity projects; an exception is given to companies that generate power for their own use or those using renewable energy; this way they can set up plants independently without having to partner with PLN

- To delineate measures for the enhancement of energy supply security

- To provide development road maps for various sectors, covering renewable and non-renewable energy sectors

- To design programs to phase out subsidies and improve energy efficiency

- To set energy diversification targets for 2025 ; including $5 \%$ biofuel, and $5 \%$ geothermal and other renewables such as biomass

- To set an energy conservation target of reducing energy intensity by $1 \%$ per year

- To set a target for biofuel utilization

- To set the guidance for multi-sector coordination in biofuel development

- To extend the same price guidelines as Ministerial Decree no. 1122/2002 for projects from $1 \mathrm{MW}$ to $10 \mathrm{MW}$

- To regulate renewable energy development and energy efficiency policy, particularly by increasing the utilization of renewable energy and provide incentives for renewable energy developers for a certain period of time

- To invite private companies to participate in electricity supply

- To give higher priority for the use of renewable energy and clean technology for electricity supply

- To encourage more utilization of small-scale distributed power generation from renewable sources such as from biomass energy 


\section{Biomass energy strategies: Articulation and execution}

This section covers different strategies articulated and executed by India and Indonesia for harvesting biomass energy potential, though these strategies are not well organized and classified in each country. We will do a descriptive analysis with a holistic approach under three areas of biomass energy utilizations: household energy use, power, and transport.

\subsection{India}

India's strategy for utilization of biomass energy basically articulates and follows the policy on biomass energy. The strategy execution process covers various biomass programs for household, power, and transport segments for achieving the policy targets. These programs are undertaken at different scales and levels, right from small to large scale technology/application/ system and from micro to macro levels of implementation.

\subsubsection{Biomass for household energy use}

Due to shortage or lack of electricity supply, most of the rural households use wood as biomass for cooking and heating. The government had taken up programs to improve this traditional way of using biomass for meeting household energy needs. Biogas and Efficient Cook Stoves programs are two such major programs for the promotion of appropriate rural based biomass technologies.

Biogas promotion in India started in 1962, when the first Biogas plant, i.e., Khadi and Village Industries Commission (KVIC) Floating Dome Model (Indian Model), was commissioned. But here, seriousness was missing until 1979, when the First Fixed Dome Model was commissioned. A large initiative, National Biogas and Manure Management Program (NBMMP), for further utilization of this medium scale technology was launched in 1981. At the micro level, this program was aimed at providing family type biogas plants for household energy needs for cooking and water heating purposes [23]. While at the macro level, it was focused on mitigating drudgery of rural women, forestry conservation, and in the long term to mitigate climate change by preventing black carbon and methane emissions [23].

Until this moment, NBMMP is still being implemented by SNA and KVIC $[14,23]$. Such a program faced challenges of financing such small biogas plants and motivating rural adopters. Therefore, NBMMP got strong support from Central Finance Assistance (CFA) in the form of a capital subsidy in fixed amount. Such a capital subsidy addressed multiple challenges through multiple options and offers, e.g.: the turn-key free job, including five years warranty; incentive for saving conventional fuels by using biogas as the engines fuel; training course for users, staff, and operators; Biogas Development and Training Centre at the state level; and publicity/communication [23].

The National Biomass Cookstoves Initiative (NBCI) was the second program, launched in December, 2009, by MNRE, with emphasis on enhancing the country's technical capacity in providing clean and efficient energy for the poorer and energy deficient rural areas [24]. The key thrust was on energy inclusion, efficiency and health through a series of pilot scale project namely "A New Initiative for Improved Cookstoves" for exploring a range of technology deployments. The collaborative approach among SNA, university/research institute, and non-governmental organization (NGO) was adopted for accelerating large scale deployment of improved cookstoves [24].

\subsubsection{Biomass for power}

The potential of surplus biomass for power production in India is estimated at about $18,000 \mathrm{MW}$ [25]. Such a potential has made strategy articulators and executors more convinced and motivated to work with greater focus on using biomass for power production. Therefore, biomass power generation is becoming an emerging industry in India over the last decade. It attracts an annual investment of over USD 130 million and produces about 5000 million units of electricity with 10 million man-days jobs in rural areas $[25,26]$. To realize the potential, the government has undertaken a number of programs for biomass power generation through two major schemes-grid interactive and off-grid, and distributed renewable power.

The Biomass Power/Cogeneration Program, a grid interactive and off-grid program of MNRE was implemented in the mid1990s for efficiently using biomass to increase power supply with macro level focus. Here, the objective was to promote large scale technologies such as biomass combustion for power generation and cogeneration in sugar mills [27]. In terms of funding, it has provided financial and fiscal incentives for the industrial sector at the state level, in particular sugar mills, for participating in cogeneration projects [27].

Biomass Energy and Cogeneration (Non-Bagasse), a sectororiented program for distributed renewable power production for industry, was implemented by MNRE in 2005 [28]. Unlike the Biomass Power/Cogeneration Program, which focuses mainly on sugar mills, this program covers broader industries like pulp and paper, textiles, fertilizers, petroleum, petrochemicals, food processing, etc. It promotes medium to large scale biomass technologies, e.g. biomass gasifier and biomass cogeneration (nonbagasse), in order to supply heat and electricity for industrial operations. At the macro level, this program encourages deployment of biomass energy systems and promotes distributed power generation for feeding surplus power in the main grid. The long term aim is to reduce total GHG emissions, particularly from the industrial sector.

The Biomass Gasifier Program or Biogas based Distributed/Grid Power Generation Program, another distributed biomass power, was implemented through collaborative efforts of SNAs together with Energy Services Companies (ESCOs), Panchayats (village government), NGOs, and manufacturers or entrepreneurs $[29,30]$. At the micro level, it focused at promoting and increasing small capacity range of biogas power generation based on wastes from animal, forestry, kitchen, and agro/food processing. It is mainly for meeting electricity demands of households, village communities, and small scale industries in electrified villages. Therefore, the projects are mostly taken up by any village level organization, institutions, and private entrepreneurs in rural areas for selling electricity to individual, community, and grid based on mutual agreements [30]. At the macro level this program is oriented to promote demonstration projects for $100 \%$ producer gas engine, coupled with gasifier for off-grid and grid power operation [29].

More additional initiatives from the central and state governments are undertaken to capture the biomass energy potential. But it required a credible assessment. Therefore, the Government initiated the National Biomass Resource Assessment Program (NBRAP) for developing biomass assessments.

At this point, the required financial facility as subsidy is provided by IREDA, on behalf of the central Government for capturing biomass potential through setting up biomass power and bagasse cogeneration projects [27]. Furthermore, CFA, fiscal incentives, and the state-level actions are additional supports to central initiatives. CFA usually covers capital subsidy for the surplus of power exported to the main grid. CFA also gives support to cogeneration projects based on conventional fuels, but this support is limited only for promotional and awareness creation activities. Fiscal incentives generally consist of accelerated depreciation (i.e., equipment required for cogeneration system), concessional import duty, income tax holidays, customs 
duty, and exemption of general sales tax. Customs duty incentives such as concessional custom duty and excise duty exemption are usually provided for initial setting up of biomass projects after being assessed by MNRE [27].

Many initiatives are also introduced to further accelerate the implementation of the programs at the state level [14,27], as described in the following three points:

1. Funding opportunities for small to large scale technology/ application/system at the micro and macro level implementation, including grants and contracts, loans, equity investments, direct incentive payments for project setup and installation activities, business development and equity.

2. Purchasing biomass power under state specific incentives in the form of preferential tariffs and buyback/banking of generated electricity by the State Electricity Corporations and Boards.

3. Obligation for power/electricity companies to produce a specified share of their electricity supply from biomass and other renewable energy sources. This obligation is placed under Renewable Portfolio Standards (RPS) provided by State Electricity Regulatory Commissions. Among the states that have placed the RPS are Tamil Nadu (10\%), Karnataka (7-10\%), Maharashtra (3-6\%), and Andhra Pradesh (5\%).

\subsubsection{Biofuels for transport}

The rising consumption and imports of fossil fuel, along with increased $\mathrm{CO}_{2}$ emission, forced the government to explore biofuel as a clean and cost effective fuel option. Indian biofuel strategy focused on the use of bioethanol and biodiesel, produced from non-food resources. Ethanol is produced from sugar molasses and biodiesel is produced from non-edible oils and oil waste. Ethanol is blended with petrol while biodiesel is blended with diesel. The strategy had targeted the blending of $5 \%$ bioethanol in petrol by 2010 [31]. In addition, the government facilitates and brings about the optimal development and application of indigenous biomass feedstocks for biofuels production [31,32]. Furthermore, recently, the strategic plan of new and renewable energy 20112017 encourages the exploration of advanced conversion technologies for second generation biofuels. It envisages research and development of more efficient biofuel conversion technologies for biofuels production [33].

Looking at biomass energy strategy in India, the government has given emphasis firstly on biomass for household energy, such as biogas, and then on biomass power and lastly on biofuel over time. MNRE takes the lead to develop and deploy the strategy. The initiative on biogas has been taken a longer time compared to biomass for power and transport. However, the whole strategy was to focus on developing technology for domestic purpose, promoting research and development, implementing technology development programs, development of different sectorial capabilities in terms of institutions, and promoting private investments, especially in biomass for power. Similarly, in the next section we will provide a descriptive analysis on how the biomass energy strategy has been developed, articulated, and executed in Indonesia.

\subsection{Indonesia}

The strategy for biomass energy utilization in Indonesia has been developed by following the policies related to biomass energy, mainly the National Energy Policy. Therefore, the strategy encompasses multiple objectives such as enhancing energy security and sustainable development, reducing dependence on fossil fuels, alleviating poverty and creating jobs in rural areas. The strategy has been articulated and executed through taking up several programs and initiatives at different scales and levels of implementation; right from small to large scale technology/ application/systems. Each program poses different orientation, from micro to macro level, and from short-term to long-term orientation.

\subsubsection{Biomass for household energy}

Biomass, for a long time, has been traditionally used for household energy needs for cooking and water heating in Indonesia. Two major biomass sources, wood and agricultural wastes, among others, are used for cooking in rural areas. But such use cannot be said as sustainable use, because these biomass technologies are still not efficient and environmentally friendly. Indonesian strategy is not well organized to promote biomass for household energy usage, but some programs have been carried out by the government to improve the usage of biomass for household energy. These programs are mainly focused on promoting the use of biogas technology and cookstoves for rural areas [34].

The biogas program consists of installation of a demonstration plant and training for digester operation. In addition, research activities on biogas technology are also carried out by universities to support its implementation. For cookstoves, the government conducts the biomass characterization of briquette technology for cookstove fuels. The cookstoves program is focused on the reduction of environmental impact and efficiency improvement [34]. In terms of implementation scale, the biogas program has larger scale than cookstoves program. The biogas program is focused not only on single household use of the digester but also on collective use. One biogas digester, depending on its capacity scale, can supply energy to a number of households. Meanwhile, the cookstoves program is oriented for singe household usage due to the design of the cookstoves [34]. However, due to the relatively low price of kerosene and subsidized liquefied petroleum gas (LPG) bottles, most households were not interested in using biomass cookstoves and the biogas program. The ease of obtaining kerosene and LPG bottles in the market also made them more preferred over biomass cookstoves and the biogas program among households. The activity of both programs (biomass cookstoves and biogas) then only got little emphasis. Therefore, biomass cookstoves and the biogas program were not deployed extensively and efficiently.

\subsubsection{Biomass for power}

The potential of biomass power production in Indonesia is estimated to be equivalent to $50 \mathrm{GW}$ by national studies[7] Therefore, the government strategy considers it as important to utilize the abundant biomass resource for increasing power production and supply in order to meet national demand and reduce the dependence on fossil fuels. The main policy challenges were sustainability and supply of power. These challenges provide opportunity to strategy executors to focus on utilization of new and renewable energy (i.e., biomass) as alternative to deal with the above issues [35]. Palm oil, rice husk, bagasse and municipal wastes are the biomass resources under focus to develop for power generation [22]. The strategy to harvest this potential adheres to biomass energy policies such as Small-Scale and Distributed Power Plant, and Medium Scale Power Generation from Renewable Energy.

The strategy on distributed power plants is oriented to meet the energy demand at small and medium scale local industries such as rice mills, and also to replace diesel power plants of the 
State Electricity Company (PLN) [22,36]. Small and medium scale biomass combustion and gasifier, and also combined heat and power (CHP), are the biomass technologies used in this program. Some projects have been undertaken through collaborative effort between ESDM and PLN, and supported with research activities on biomass technology by several universities and the National Agency for Research and Technology (BPPT). Most of power plants in rural areas in Indonesia are diesel based, which is the off-grid type. Therefore, the small and distributed power plant strategy is focused on executing at the rural and certain urban areas, with and without access to the electricity grid. When there is access to the grid, small power producers can generate electricity (normally up to $15 \mathrm{MW}$ ) and interconnect to the medium and low voltage national electricity grid. The exported electricity then will be purchased by PLN at the determined sales price.

The strategy execution has also put attention on the development of the biomass gasification technology by conducting pilot projects and supporting research activities. Since 2000, the government has carried out research and development on integrated rice mills for heat and power production with biomass gasification in West Java [36]. The focus is to improve the production capacity of gasifiers in order to reduce the production cost. Therefore, biogas gasification based power plants and cogeneration become more economically feasible and ready to be commercialized on a larger scale. In fact, however, biomass power generation has been commercially used in large sugar and palm oil plantations in Indonesia before the government carried out its programs. Most of these plantations used medium to large scale biomass technology such as steam boilers for producing heat and power $[15,37]$.

At the macro level, the strategy on biomass for power is oriented to increase the electrification ratio of the country from distributed power systems by further accelerating the deployment of decentralized biomass based power plants. This strategy is part of the sustainable development of the country as reflected in the replacement of diesel power plant of PLN. Therefore, the government has encouraged the utilization of biofuels, especially biodiesel and pure plant oil (PPO), for PLN diesel based power plants. Such initiatives require strong support in terms of finance, investment and incentives, such as giving fiscal and tax incentives, developing public-private partnership for project funding, simplifying credit procedures for biomass power projects, and promoting biomass power projects by financial institutions $[22,36]$.

\subsubsection{Biofuels for transport}

Due to growth of transport activities, in particular private vehicles, the consumption of fossil fuels as the main fuel is growing rapidly in Indonesia over the last decade. On the other side, domestic oil production is decreasing. Therefore, Indonesia is increasingly dependent on imports of oil to meet its energy demands. The rising consumption of oil in the transportation sector has also contributed to increased $\mathrm{CO}_{2}$ emissions. In order to address this issue, the strategy execution process has been focusing on encouraging the utilization of biofuels as an alternative transport fuel. To accelerate this adoption process, in 2006, the government formed the National Biofuel Development Team (TimNas BBN) for developing a strategy for biofuels supply and use [22].

At the micro level, the biofuels strategy for transport steered substitution of petrol by bioethanol from sugar and cassava, and diesel by biodiesel from palm oil and Jatropha curcas $[38,12]$. Additionally, the production of bio-oil from vegetable oil and biogas are also promoted. On the macro level, the long term vision focused strategy has been oriented to take benefit and sustainable long-term returns from the biofuel economy. In terms of funding, the strategy covers investment and financing scheme in biofuels development, and the price mechanisms in the biofuels supply chain.

On the supply side, the strategy is focused on increasing the local potential of biofuels development and improving feedstock supply. In order to improve the production and utilization of biofuels, the government is also focusing on accelerating land availability and developing "Special Biofuel Zone" [15,22]. TimNas BBN also developed the roadmap for biofuels development. The roadmap sets short and long term steps to achieve a target of $5 \%$ share of biofuels in total energy mix by 2025 . Further, enhanced production aimed through development of large scale biofuels production plants. Moreover, the strategy envisaged to establish biofuel trading system to allow the mutual trading interaction between biofuels industry and community of suppliers (farmers) [22]. Improved local government and community participation in biofuel business was also aimed by government through the development of "Desa Mandiri Energi"(DME) or village selfsufficient energy program [22]. This participatory rural approach program utilizes biomass sources such as Jatropha curcas, palm oil, coconut, cassava, and sugar cane to produce biofuels as well as to overcome energy problem in remote areas.

Among the above three biomass energy options, so far, biofuels relatively received greater emphasis since 2006 . This is due to the reason that biofuels can be utilized not only for the transport sector but also for the power sector, especially as the substitution fuel of diesel power plants in remote areas with no access to the national electricity grid. The small and medium scale distributed power usage from biomass gasification and combustion got next priority, while little emphasis is given to utilizations of biomass for household energy such as cookstoves.

India and Indonesia have attempted at enhanced sustainable usage of biomass energy and increasing energy supply for their people. But the effects and achievements of respective policies and strategies need to be further analyzed. Therefore, the next section will focus on the effects and achievements of both countries' policies and strategies in harvesting biomass energy potential.

\section{Effects and achievements of biomass energy policies and strategies}

This section discusses the effects and achievements of policies and articulated and executed biomass energy strategies in India and Indonesia by looking into the following aspects: (a) technology development and deployment; (b) infrastructure; (c) regulation and institution; (d) human resource (HR) and knowledge development; and (e) stakeholders network development.

\subsection{India}

\subsubsection{Technology development and deployment}

India's policy and strategy on biomass energy have emphasized on the development and deployment of biomass technology. Financial incentives and policy measures have significantly advanced the technology, from small to large scale, and made it available locally as well as in different sectors. Following are the biomass technologies and applications that have been developed and deployed in India as the effect of its biomass energy policy and strategy.

4.1.1.1. Biomass combustion and cogeneration. Biomass combustion is a well established and proven technology in India for heat and power generation. Conventional boilers and turbines with capacities between 5 Mega-watt electrical (MWe) and 35 MWe are commonly 
used for the combustion process. With small modifications, such combustion technology can use various types of feedstock like sugar cane, rice husk, wood/paper, corn, palm oil, and cassava. The technology has been shaped for use at the industrial scale, such as sugar mills, and as grid-connected biomass power plants for supplying the excess electricity to the national grid in India [39]. Biomass power generation and CHP are also an advancement of biomass combustion technology for medium and large scale purposes, with capacities ranging from 1 MWe to 35 MWe. Small and medium scale biomass power and CHP plants usually require only the available local biomass source, but the large scale plants need biomass sources from a wide region and/or imported biomass sources such as wood or forestry residues. Biomass CHP is relatively a mature technology in India, while biomass power generation is now under further development for combining with gasification, called Biomass Integrated Gasification Combined Cycles (BIGCC), which offer higher efficiency and performance [40]. BIGCC is still in the industrial demonstration phase. Therefore, such policy and strategy from the government are expected to support BIGCC technology for successful market entry. Another technology emphasized by the government to be developed and deployed is the biogas anaerobic digester, with electrical capacity ranging from 10 kilowatt electrical (kWe) to $1 \mathrm{MWe}$, and is usually combined with gasfired engines for producing heat and power [6,41]. Sugar mills, paper mills, and rice mills in India have adopted cogeneration technology for heat and electricity production [39]. Such technology has been well established and locally available, and in particular, many sugar mills have used bagasse for their cogeneration plants [40]. However, the traditional usage of bagasse in most sugar mills' cogeneration produced inefficient low pressure systems, and therefore research and development on such technology has been supported by the government over the past few years in order to achieve high-pressure efficient cogeneration systems in India $[6,39]$. The additional electricity produced from cogeneration system is to be fed to the national grid for increasing national electricity capacity. More efficient cogeneration systems are expected to be adopted by many sugar mills in the coming future [6].

4.1.1.2. Biomass gasification. Biomass gasification technology (also known as gasifier) is a fairly old technology in India, an outcome of highly focused policies put in place by the government. Unlike the combustion technology that directly burns the biomass, a gasifier converts biomass to a combustible gas in a reactor and then uses it for power generation purposes [40]. A gasifier normally can operate and produce electricity at small capacity (2-10 kWe) and medium capacity (up to $2 \mathrm{MWe}$ ), yet it will be economical when operating at $5 \mathrm{kWe}$ onwards [42]. Small to medium scale entrepreneurs and business are the targets for application of biomass gasification in India. It can use a wide range of biomass, such as wood, coconut shells, fronds, corn cobs, corn stalks, briquetted biomass from saw dust, and various types of husk, like coffee, rice, and groundnut. It is also meant for electrifying remote areas with no access to the national electricity grid. Biomass gasification is still evolving in India with efforts for improving maintenance for the remote regions [40].

4.1.1.3. Tail-end biomass technology. The off-grid biomass energy application, which is also called tail-end biomass technology, is another important technology deployed through strategy articulation and policy deployment. This technology is potentially making a significant contribution to rural electrification and distributed power generation. This technology is expected to reduce transmission losses by $5-7 \%$ and thus can improve the availability of power in remote regions. The concept of this technology involves the utilizations of biomass gasifiers with small scale capacity from
$1 \mathrm{MW}$ to $2 \mathrm{MW}$. This concept has been further formulated to achieve the target of $200 \mathrm{MW}$ biomass gasifier projects at the tail end of the grid by 2022 [6].

Besides the above biomass technologies, options such as biomass liquefaction via pyrolysis, and organic plant based oil are also available though still in limited use [6]. Pyrolysis technology is a similar process to gasification and the produced oil can be combusted in the boiler for heat and electricity generation. Organic plant technology usually uses crude palm oil (CPO) for generation of electricity. Both of these technologies are supported by the policies for further development and deployment, in particular for power generation. Recently, the government has taken a new initiative for bottling of biogas to demonstrate an integrated technology package oriented for medium size mixed feed biogasfertilizer plants (BGFP) in entrepreneurial mode [43]. The demonstration activity covers purification/enrichment, bottling, and piped distribution of biogas. About 21 BGFP projects with a total capacity of $37,016 \mathrm{~m}^{3}$ per day have been approved by MNRE for implementation by the end of 2011 [43].

The policy incentives on biomass cogeneration and gasification technology for adoption and adaptation in the market also create an impact for the development of other industries [46]. For instance, the residues of the food processing industry need to be disposed of; they can be converted into energy by using biomass cogeneration and gasification technology. It offers alternatives for supplying power as well as handling the residues. These are the steps which drive the development of small to medium size food processing industries at the village level and in remote areas.

\subsubsection{Infrastructure}

The adopted and deployed biomass energy policy and strategy articulation and execution in India led to several achievements in energy infrastructure. Until 2011, the total installed capacity of biomass power and cogeneration (bagasse) has reached about $2862 \mathrm{MW}$ and has been used for feeding power to the electricity grid [44]. This installed capacity is also the result of about 288 deployed biomass power and cogeneration (bagasse) projects $[27,45]$. About 135 projects are still under various stages of implementation, and in the near future these projects are expected to provide additional capacity of about $1700 \mathrm{MW}$ of electricity [45]. A surplus capacity of $800 \mathrm{MW}$ is expected to be provided from around 70 on-going cogeneration projects [27]. In addition, there is an overall potential to generate $5000 \mathrm{MW}$ of power from the bagasse available from Indian sugar mills through highly efficient cogeneration systems [6]. Bagasse cogeneration projects have prominently been implemented in several states like Andhra Pradesh, Tamil Nadu, Karnataka, Maharashtra, and Uttar Pradesh. Andhra Pradesh, Maharashtra, and Tamil Nadu are also known as the leading states for biomass project implementations, together with Chhattisgarh, Madhya Pradesh, and Gujarat [27]. These achievements have benefited India in increasing its energy supply for small scale usage as well as medium and large scale usage.

In the off-grid/distributed biomass power programs, about 469.38 MWe biomass cogeneration (non-bagasse) and gasifiers have been installed as of August, 2012 [44]. The gasifiers that have been deployed at the industrial sector accounted for 137.65 MWe and in rural areas accounted for 16.25 MWe [44]. Another strategic achievement at the micro level is the deployment of family biogas plants. Cumulatively, about 45.45 lakh family biogas plants have been installed throughout India [44]. This achievement has increased the household energy supply in India. Table 3 shows the major cumulative achievements of biomass energy programs in India up to August, 2012, covering grid-interactive, off-grid/distributed, and family biogas plants. 
Table 3

Major cumulative achievements of biomass energy programs in India up to 2012. Source: [44].

\begin{tabular}{ll}
\hline Biomass energy programs & $\begin{array}{l}\text { Cumulative achievement } \\
\text { up to August 2012 }\end{array}$ \\
\hline $\begin{array}{c}\text { A. Grid-Interactive Power (MW) } \\
\text { Biomass cower }\end{array}$ & 1209.60 \\
Biomass cogeneration (bagasse) & 2109.73 \\
$\quad$ Total grid interactive & 3319.33 \\
B. Off-grid/captive power (MWe) & 398.40 \\
Biomass cogeneration (non-bagasse) & 16.25 \\
Biomass gasifier & 137.65 \\
Rural $\quad 552.30$ \\
Industrial \\
$\quad$ Total off-grid & 45.45 \\
\hline
\end{tabular}

In the recent past, biomass gasification technology had been prominently used for power production in remote regions. However, due to several maintenance difficulties in the remote regions, it is less deployed. Currently, India's installed capacity for biomass gasification for power production is about $153 \mathrm{MWe}$ [44]. Through technology advancement and government support, such production capacity is expected to be enlarged. Furthermore, the policy and strategy have increased the manufacturing capability of the biomass power plants and equipment. Most of the infrastructure and applications in the biomass projects have been provided from indigenous sources. For instance, more than 15 manufactures have been approved by MNRE to develop biomass gasifiers with capacity of $5 \mathrm{~kW}$ to $1 \mathrm{MW}$ [43].

Meanwhile, only small achievements can be found with regards to biofuels policy and strategy. Currently, the blending target of 5\% ethanol in petrol is not successfully achieved in India until 2011 [46]. The production of biodiesel is also not significant to fulfill the government's blending target of $20 \%$ of biodiesel to conventional diesel. Therefore, this target too was nonviable to achieve until now [46]. One of the reasons is the lack of availability of sufficient seeds such as Jatropha curcas for producing biodiesel. Furthermore, the lack of physical infrastructure necessary to support the biofuels industry is still the major hindrance in success of India's biofuels policy and strategy. India is constrained by land availability and scarce water resources for expanding feedstock cultivation, which is needed for large scale biofuel production [47].

\subsubsection{Regulation and institution}

A number of regulations have been issued and implemented in India as part of its policy and strategy for harvesting biomass energy potential. These regulations are aimed to govern and support the utilization of biomass in terms of project financing scheme, fiscal incentive, tax incentive, and tariff pricing. The electricity act of 2003 is the most important law for creating a regulatory framework and structure. Along with these regulations, the government has also created several institutions to support the development of biomass energy sector. The most important achievement is the reformation of MNES to MNRE in year 2006 as the highest institution in the new and renewable energy sector in India. In addition to this institutional achievement is the creation of IREDA as a financial institution dedicated to support renewable energy development, including biomass.

\subsubsection{HR and knowledge development}

The policy and strategy on biomass energy in India have emphasized human resource and knowledge development. Therefore, it has been acknowledged by the government as an important factor for developing the biomass energy sector as well as the renewable energy sector [26]. Here, the achievements on HR and knowledge development are measured in terms of the provision of capacity building programs and its related activities. An important achievement is the establishment of Sardar Swaran Singh National Institute of Renewable Energy (SSS-NIRE) [48]. This autonomous institute of MNRE focuses on carrying out state-of-the-art research and developmental activities in the area of bio-energy, including human resource development, and research for commercialization of renewable energy technologies in India. The National Renewable Energy Fellowship program under MNRE, dedicated to the research and development of renewable energy in India, including solar, wind, biomass, and other renewable energy sources. Since the program started in 2000, not less than 50 fellowships are provided to junior, senior and post-doctoral research fellows every year [49]. A recent initiative from MNRE is the 'SSS-NIRE Bioenergy Promotion Fellowship' convened by SSSS-NIRE. Currently, seven fellowships in the field of bioenergy have been granted to seven research fellows from junior to post-doctoral levels. The research themes cover biomass characterization, plantation, management, and conversion technology, biofuels, algal biomass production, and bio-hydrogen production [48].

\subsubsection{Stakeholders network development}

The policy deployment and strategy articulation and execution have resulted in development of stakeholders' networks at local, regional, national and international levels. This, for instance, has helped the government in building cooperations for project financing, execution, transfer of technology, and other mutual cooperations. Numbers of parties have been collaborating for developing the biomass energy sector in India, and few can be highlighted here. At the domestic level, the stakeholder network has been developed through collaborative effort from the ministries (e.g. MNRE, Ministry of Finance, etc.), state governments, village governments, research institutes/universities (e.g. Indian Institute of Science), bank and financial institutions (e.g. NABARD—National Bank for Agriculture and Rural Development and IREDA), industries, NGOs, communities in rural areas, and other institutions at the country level and private companies $[6,33]$. At an international level, a number of multinational companies and international institutions (e.g. USAID-US Agency for International Development) involved in the biomass power plants supply chain have also affected the more extensive stakeholder network [32]. Several United Nations branch organizations are also actively involved in the development of the Indian biomass sector. The prominent ones are the United Nations Development Program (UNDP) and the United Nations Industrial Development Organization (UNIDO).

\subsection{Indonesia}

\subsubsection{Technology development and deployment}

With huge potential of biomass, Indonesia is an attractive market for biomass technology. So far, biomass technology development in Indonesia has been focused on the low cost of biomass residue combined with high electricity demand and decentralized/ distributed power plants, especially in small to medium scale industries. Strategies have also been focused on improving the production capacity of biofuels for supplying transport fuels as well as substitution fuels in diesel based power plants. However, the development of biomass technology is relatively slow. Most such technological deployments can be found mostly in plywood and agricultural industries such as sugar cane, saw mills, rice mills, and oil palm plantations. Following are the biomass technologies deployed so far in Indonesia. 
4.2.1.1. Biomass combustion and cogeneration. Biomass combustion technology is relatively well established in Indonesia. Such technology, like boilers, is the common biomass combustion technology used for heat production or in cogeneration plants in combination with steam engine for electricity generation. These technologies have typical capacity up to $5 \mathrm{MW}$ and have been used in sugar factories, plywood industries, and palm oil plantations in Indonesia [50]. However, feeding the surplus power to the electricity grid and supply to remote areas are still limited. Until the year 2013, biomass cogeneration is still being deployed under few projects in several agro industries. Biomass power is still expected to be deployed for increasing national electricity capacity under distributed small and medium power generation programs [51].

4.2.1.2. Biomass gasification. Gasification of rubber wood from unproductive rubber trees, charcoal, wood sawdust and rice husk has been empirically tested and used for replacing diesel based engines as the electricity generation for rice mills, saw mills, and other small to medium scale industrial usage. Several types of gasifier have been developed so far with the power capacity of $10-100 \mathrm{kWe}$. The Bioner-1 downdraft gasifier with power capacity $18 \mathrm{kWe}$ has been designed for replacing diesel based engines used in the rice mills. Rice husk as a major biomass source is used in this gasifier [22,36]. The rice husk gasifier in Haur Gelis, West Java, is another gasifier with a larger capacity than Bioner-1. It has a capacity of $100 \mathrm{kWe}$, which is suitable for medium to large scale rice mill factories $[22,36]$. Most gasifiers at the small and medium scales are deployed in Java nowadays. The Agency for the Assessment and Application of Technology (BPPT) has also developed a number of combined gasifier technologies. First is the fixed-bed combined gas engine gasifier for power generation with a capacity of $40 \mathrm{kWe}$, and the second is the fluidized bed combined gas burner gasifier for heat production with capacity of 80 kilo-watt thermal (kWth) [52]. Biomass gasification sourced with coconut waste feedstock with capacity of 40 kilo-volt ampere (kVA) to $50 \mathrm{kVA}$ is also being developed [53].

4.2.1.3. Biomass to liquid production (biofuels production). Design and engineering of biodiesel pilot plant production has been developed under strategy execution process in Indonesia with production capacity of $1.5-8 \mathrm{t} / \mathrm{d}[22,52]$. Low grade crude palm oil (CPO) plants are relatively well established for the large scale, but the large production facilities that aimed to use Jatropha curcas are still underway. In this regard, the Indonesian Center for Agricultural Engineering Research and Development (ICAERD) has partly modified the seed oil extractor for Jatropha oil extraction with the production capacity of $70-80 \mathrm{~kg}$ of seeds per hour [54]. A bioethanol manufacturing facility with new dehydration technology has also been designed with production capacity of $250 \mathrm{~L} / \mathrm{d}[22,55]$. It is aimed to improve the quality of bioethanol from technical to unit fuel grade. Cassava and sugar cane are commonly used for this bioethanol production. The Oil and Gas Institute (LEMIGAS) has tested the blending of biodiesel with automotive diesel oil (ADO) in the ratio of 30:70 for commercial diesel engine usage [55]. This research has been performed in cooperation with the State Oil Company (Pertamina) since 1996 and is still carried out for improving results. Now LEMIGAS focuses in the testing methods of biodiesel fuel properties for improving the effect of biodiesel on engine performance. For future research, BPPT has planned to further improve the bio-refinery technology that encompasses biomass to liquid production and biomass gasification, and also biomass processing and handling to support biomass energy development [52].

Unlike India, where the policy incentives on biomass technology development and deployment also impact the food processing industry, it is unclear whether such policy incentives in Indonesia have created any impact to the development of other related industries.

\subsubsection{Infrastructure}

Despite huge potential of biomass source for power production (about $50 \mathrm{GW}$ ), its utilization is still low. It is also found quite often that due to economic reasons, biomass sources like palm oil (for biofuels) are exported than being utilized for domestic usage, i.e., for biomass energy. It also reflects that biomass has not been well utilized seriously for domestic energy supply. The recent utilization of biomass energy is estimated to be only $1600 \mathrm{MW}$ or about $3.25 \%$ of the existing potential [37]. In 2009, the installed capacity of the biofuel power generator by PLN was about $116 \mathrm{MW}$ [56], and then in 2010 the total installed capacity for biomass power is only about $443 \mathrm{MW}[22,57]$. It is expected that in the near future the installed capacity can be increased by further accelerating the small-distributed power programs.

Until 2007, Indonesia had more than 10 bioethanol manufactures with relatively large scale production capacity ranging from 3.6 million liters per year to 50 million liters per year [58]. About 95\% bioethanol producers are aiming at industrial purpose. However, Indonesia bioethanol program had been terminated since 2010. This is due to disagreement between ESDM and bioethanol producers in formulating the market price index [59]. Meanwhile the biodiesel program is still continued, and in 2010 the production of biodiesel has reached at about 455 million liters [59]. In 2011, the installed capacity of biodiesel is about $4,253,839$ kilo liters, and from the targeted utilization at about $1,297,000 \mathrm{~kL}$, around $29.95 \%$ or $336,574 \mathrm{~kL}$ has been utilized [60].

Furthermore, it is expected that the total production capacity of biodiesel might reach more than 650 million liters by the end of 2012 [59]. Although most biofuel production is mainly originated on a large scale, small scale biofuel production or distillers are expected to grow, especially for the development of DME. At least 237 villages have been promoted to DME until 2009 [56]. Since 2009, more than 200 gas stations have been equipped with biodiesel (B-5 type) pumps in several big cities such as Jakarta and Surabaya. A few gas stations have also been equipped with bioethanol (E-5 type) pumps in the same cities [58].

\subsubsection{Regulation and institution}

Various regulations, no less than 30 from presidential to ministerial levels, have been issued to encourage the acceleration of biomass energy utilization in Indonesia [22]. These regulations address multiple issues covering supply and utilizations, project financing scheme, fiscal and financial incentive, tariff pricing, and biofuels standard. A few achievements in the creation of institutions can be seen, for example in the establishment of EBTKE as a directorate under ESDM, dedicated for policy and regulation in new and renewable energy sectors. TimNas BBN can also be regarded as an important institutional creation. It is not permanent and has less authority than EBTKE. However, it has contributed to accelerated development of biomass energy in Indonesia, especially for the biofuels development.

\subsubsection{Human resource and knowledge development}

So far, initiatives on human resource (HR) and knowledge development regarding biomass have been encouraged by the government under ESDM through collaboration between universities and research institutes, locally and internationally. One of the prominent programs is the Capacity Development and Strengthening for Energy Policy Formulation and Implementation of Sustainable Energy Project in Indonesia (CASINDO), a joint effort 
between the Indonesian government and the Dutch government started in 2009. CASINDO aims to build and strengthen human resource capacity in renewable energy, especially in the provinces of Central Java, Yogyakarta, Northern Sumatra, and Papua [61]. Such a program has been focused to promote and implement sustainable energy solutions and capacity building. CASINDO's program on capacity building mainly focuses on education and knowledge valorization. This program is followed by several universities such as the Institute of Technology Bandung (ITB), University of Mataram (UMRAM), Muhammadiyah University of Yogyakarta (UMY), University Diponegoro (UNDIP), Sumatera Utara University of Medan (USU), and Eindhoven University of Technology (TUE) as the international partner. Since 2010, CASINDO has organized four knowledge valorizations and institutionalized education program at UNDIP, UMY, and UMRAM. Each valorization workshop is attended by at least 45 participants of various universities and industries, and then followed up in form of a cooperation research between university and industry. The education program covers master program and certification in renewable energy and energy efficiency, and has been followed by 15 students [62]. Apart from this initiative, several NGOs (e.g. Dian Desa, Khaula Karya, etc.) have been providing guidance and training for the local/village farmers to the efficient and productive cultivation of biomass feedstock, e.g. Jatropha curcas.

\subsubsection{Stakeholders network development}

The policy deployment and strategy articulation on biomass energy in Indonesia have stimulated the creation of stakeholders' network in biomass energy sector, at the national and international levels. Partnerships and collaboration among stakeholders are in form of research and development, business creation, production, and trading aimed at the development of biomass energy sector. Some of such examples include Collaboration among local government, NGOs, and universities for community development at the rural areas regarding biomass. Many programs at the local/domestic level (e.g. DME) have been performed under this collaboration. At the national level, Forum Biodiesel Indonesia (FBI) has been established since 2002 to accelerate and promote biodiesel development in Indonesia. It consists of various stakeholders dealing with biodiesel activities. Several research institutions have been collaborating for years in researching and developing biomass technology such as BPPT, LEMIGAS, ICAERD, ITB, and the Indonesian Agency for Forestry and Research Development (AFRD). AFRD, which is linked with the Ministry of Forestry, has been collaborated to carry out research focusing on wood utilizations for energy production in agricultural industries. In near future, the stakeholders' network in biomass sector is expected to get extended in the National Innovation System (NIS) to promote wider cross-sectoral partnerships.

At the international level, the network of stakeholders has been developed through international partnerships in several biomass projects. UNDP, UNIDO, and USAID are few names of international organizations supporting several biomass projects in Indonesia for years. Indonesia, together with other East-Asia countries is also involved in the Biomass-Asia Project networking with the aim to contribute to the realization of a low carbon society through biomass energy utilizations.

India and Indonesia have adopted and deployed the policies, and articulated and executed strategies for harvesting their biomass potentials. Both countries have been benefited from the results and achievements of the respective policies and strategies. However, each country has witnessed different results and achievements. These differences can be used by each country for mutual sharing and learning. Therefore, in the next section we will discuss which policies and strategies are relatively more effective and efficient in harvesting the potential of biomass energy between India and Indonesia.

\section{Relative effectiveness of biomass energy policies and strategies}

Which policies and strategies are relatively more effective in harvesting the potential of biomass energy in India than Indonesia or vice versa? For addressing this question, one approach would compare the achievements of the policies and strategies so far in both countries. Comparing these achievements cannot be apple-to-apple, since different conditions exist in both countries. Therefore, in order to give a pretty clear picture, we highlight some relevant and suitable points as benchmarks to show the effectiveness of the respective policy and strategy between two countries.

An area of differing policy and strategy effectiveness between India and Indonesia has been how to prioritize the emphasis on biomass utilizations for household energy, power generation, or biofuels. India has given its sequential emphasis first to biomass for households energy consumption for a long time, the second is for biomass power, and the last is for biofuels. On the contrary, Indonesia sequentially emphasized first on biofuels, then biomass power and the last is biomass for household energy. Therefore, opposite priorities were given under strategy articulation. Such prioritization has given different results and achievements. Compared to Indonesia, India is more pro-active in stimulating the utilizations of biomass for household energy use, as can be seen from NBCI. The program is still in place till this paper is written. While in Indonesia, although the utilization of biomass is largely for traditional household usage such as for cooking and heating, it does not have such initiative at the national level with a large program. It seems the Indonesian government is not so much in favor of improving the household energy usage from biomass. But it gives more emphasis to the conversion of kerosene to the LPG based cookstoves program.

The biomass potential assessment under strategy articulation has suggested that India has potential to produce power equivalent to $18 \mathrm{GW}$ per year from agricultural and forestry residues. Moreover, there is an additional potential of $5 \mathrm{GW}$ for power generation from sugar mill industries. In 2011, the total installed capacity of biomass based power connected to the national grid has reached at about $2862 \mathrm{MW}$ or around $12.44 \%$ of total potential [44]. In addition, the total installed capacity for biomass (non-bagasse) cogeneration and biomass gasifiers (rural and industries) are at about 507 MWe. Meanwhile, Indonesia has a large biomass potential at about $50 \mathrm{GW}$, but it could capture only around $1600 \mathrm{MW}$ or about 3.25\% from the existing potential [22]. In 2009, the installed capacity of biofuel power generator by PLN was about $116 \mathrm{MW}$ [56], and then in 2010 the total installed capacity for biomass power was only about $443 \mathrm{MW}[5,57]$. Most of its utilizations are for distributed power in commercial industries, but not yet for feeding to the national grid. Apparently, by looking at these achievements in both countries, India has a more effective policy implementation and strategy execution than Indonesia in terms of biomass utilizations for power and electricity generation. Compared to Indonesia, India has more solid and concrete initiatives to accelerate the programs of biomass for power in particular at the state level. This can be seen in terms of funding opportunities for project activities, preferential tariffs as the incentives for purchasing biomass power, and RPS. These three initiatives are complementing, resulting in significant numbers of installed capacity.

India's own achievement in biofuels utilization is not as good as biomass utilization for power generation. While every year 
there is a significant increase in the installed capacity for biomass power, the implementation of compulsory biofuel blendings (e.g. bioethanol and biodiesel) in petrol is pending and still far from achieving the target. The production of biofuels in India is still commercially insignificant, which makes biofuels economically unviable as an alternative transport fuel at this moment. On the surface, Indonesia's biodiesel production appears to have a significant increase as well as its utilization, especially in 2011. In contrast, the utilization of bioethanol is still $0 \%$ in Indonesia [60]. Thus, Indonesia considered to have better achievements than India in terms of biodiesel production and utilizations. However, in terms of effectiveness of both countries policy and strategy on biofuels utilizations (not only biodiesel, but including also bioethanol and other liquid fuels), both India and Indonesia still need significant improvements in order to achieve better results.

India's biomass energy policy is more institutional oriented and more top-down approach rather than bottom-up. This led to the creation of dedicated institutions dealing with renewable energy sector including biomass, i.e., MNRE, IREDA, and SSS-NIRE. Furthermore, India's strategy is also oriented to create strong regulatory system which can promote renewable energy source including biomass. This is also driven by the philosophy of lack of competitiveness between fossil fuels based electricity and biomass based electricity generation. Therefore, some regulations are addressed for supporting the biomass based electricity generation, e.g. fiscal and tax incentives, feed in tariff pricing, share of renewable power generation, etc. The created institutions have strong authority, especially MNRE, in terms of issuing regulations, providing project funding (i.e., through IREDA), carrying out research and development, and other related authorities in the development of renewable energy. Unlike India, Indonesia has less institutional creation oriented and has no dedicated institutions dealing with the renewable energy sector at the ministerial level. EBTKE, which focuses on new and renewable energy development, is only a directorate under ESDM. At this moment, Indonesia has no financial institution dedicated to funding the development and deployment of the biomass energy program, while India has IREDA. In terms of human resource and knowledge development, Indonesia also has no dedicated institution focusing on biomass energy, while India has SSS-NIRE. Nevertheless, such effort is carried out through joint collaboration between local and international institutions like in the CASINDO program.

India's policy evolved from incremental to radical change approach, while Indonesia remains with the incremental change approach. India's policy on fiscal and tax incentives also seems more progressive than Indonesia. The different effects of this approach can be seen clearly in the achievement of biomass utilizations. Biomass for power/electricity is such an example, where in both countries it is put as the second priority of utilization. However, India shows larger installed capacity than Indonesia. The creation of such dedicated institutions with large authority have been proved more effective in terms of policy formulation, regulatory support, project funding, and research and development of technology and accelerating the development of the biomass energy sectors in India than Indonesia. Although in Indonesia too various regulations have been issued to guide and support the utilizations of biomass energy, as indicated by ESDM, the effectiveness of these regulations is still far from expected. This is indicated from the achievements so far in Indonesia compared to India. Therefore, in terms of institutional creation policy and strategy, India seems relatively more effective than Indonesia. And thus, as elucidated above, apparently India's general policy implementation and strategy articulation are also relatively more effective than Indonesia in harvesting biomass energy potential.

\section{Conclusions}

Both India and Indonesia are endowed with abundant biomass resources. However, they harvest their biomass energy potential with fundamentally different deployed policies and articulated strategies. India's policy evolved from an incremental to a radical approach, focusing on institutional creation to dedicatedly support the promotion of biomass energy sources. This has led India to have a relatively unified biomass energy strategy. In contrast, Indonesia has been following an incremental change approach. It has less focus on institutional creation for promoting and capturing biomass energy potential. As a result, Indonesia has no strong and dedicated institution dealing with the biomass energy sector as well as no solid and unified biomass energy strategy.

The Indian policies and strategies related to technology have been focused on developing and deploying more efficient technologies by sourcing them from domestic sources as well as international. Indonesia has not given much importance to domestic technology development by focusing on domestic needs. Biomass energy technologies have been facing competition from fossil fuel technologies for their deployment in Indonesia, contrary to India, where tax, institutional and subsidies support.

The transitions in terms of policies and strategies are faster in India as compared to Indonesia. The institutional, technological and landscape transitions would be creating a difference in outcomes in the biomass sector of two cases. Therefore, India is passing through radical and fast systemic transitions for harvesting biomass resources. Both countries also pose different achievements in biomass energy utilization, and in general, India seems to have larger achievements than Indonesia. Although these achievements cannot always be compared apple-to-apple and used as a standard of success, in such a way it seems that India has more effective biomass energy policy and strategy than Indonesia.

Biomass energy potential in both countries can be seen as an important factor in transition towards sustainable energy supply. Therefore, we also suggest future research to further analyze the problem and challenge of bioenergy transitions in India and Indonesia. Such an approach for this purpose would be a multilevel perspective looking at transitional phenomena in the respective countries. And furthermore, it is to elaborate such strategy to accelerate biomass energy utilization in both countries.

\section{References}

[1] CSO. Quarterly estimates of gross domestic product for the second quarter of 2011-12, 2011. Central Statistics Office, Ministry of Statistics and Programme Implementation, Government of India.

[2] BPS. Laporan Bulanan: Data Sosial Ekonomi. Badan Pusat Statistik (Statistics Indonesia) 2012

[3] Enerdata. Global energy statistical yearbook 2011. Total Energy Consumption 2011; Available from: 〈http://yearbook.enerdata.net/2010-energy-primaryproduction.html\#/2010-energy-consumption-data.html $>$; [accessed 20.12.11].

[4] MOSPI. Energy statistics 2012, 2012. Central Statistics Office, Ministry of Statistics and Programme Implementation, Government of India. New Delhi, India.

[5] ESDM. Blueprint Pengelolaan Energy Nasional 2006-2025. Departemen Energi dan Sumber Daya Mineral Republik Indonesia. Jakarta; 2006.

[6] MNRE. Future potential of biomass energy in India. Bioenergy India 2011.

[7] ESDM. Bioenergy potential in Indonesia reached 49.810 MW. Available from: <http://www.esdm.go.id/index-en/83-energy/4536-bioenergy-potential-i n-indonesia-reached-49810-mw.html $\rangle ; 2011$ [accessed 20.12.11].

[8] Maniatis K. Biomass gasification in Indonesia. Biomass 1989;18(3-4):221-39.

[9] Ravindranath NH. Biomass gasification: environmentally sound technology for decentralized power generation, a case study from India. Biomass and Bioenergy 1993;4(1):49-60.

[10] Pallav P. Economic potential of biomass gasification projects under clean development mechanism in India. Journal of Cleaner Production 2009;17(2): 181-93. 
[11] Suntana AS, et al. Bio-methanol potential in Indonesia: forest biomass as a source of bio-energy that reduces carbon emissions. Applied Energy 2009;86(1):S215-21 [0].

[12] Silitonga AS, et al. A review on prospect of Jatropha curcas for biodiesel in Indonesia. Renewable and Sustainable Energy Reviews 2011;15(8):3733-56.

[13] Restuti D, Michaelowa A. The economic potential of bagasse cogeneration as CDM projects in Indonesia. Energy Policy 2007;35(7):3952-66.

[14] Ravindranath, D, SSN Rao. Bioenergy in India: barriers and policy options, 2011, UNDP India.

[15] Senoaji, A. Policy and regulation of renewable energy in Indonesia. GIZ Workshop. Berlin; 2011.

[16] Shukla, PR. Biomass energy in India: policies and prospects. In: Proceedings of Biomass Energy: Key Issues and Priority Needs. Organized by International Energy Agency (IEA). Paris; 2000.

[17] MNRE. About us. Available from:〈http://www.mnre.gov.in 〉; 2012 [accessed 20.02.12].

[18] Planning Commission. Eleventh five-year plan, 2007-2012. Government of India. New Delhi; 2007.

[19] GOI. National Action Plan on Climate Change 2008.

[20] MNRE. Policies. Available from: 〈http://mnre.gov.in/〉; 2012 [accessed 20.10.12].

[21] USAID. From ideas to action: clean energy solutions for Asia to address climate change. Indonesia Country Report 2007.

[22] ESDM. Ministry of Energy and Mineral Resource (ESDM). Available from: 〈www.esdm.go.id >; 2011 [accessed 20.12.11].

[23] MNRE. National Biogas and Manure Management Programme (NBMMP) Available from: 〈http://www.mnre.gov.in/schemes/decentralized-systems schems-2/ >; 2012 [accessed 23.10.12].

[24] MNRE. National Biomass Cookstoves Initiative (NBCI). Available from: $\langle$ http://mnre.gov.in/prog-nbci.htm 〉; 2011 [accessed 20.12.11].

[25] MNRE. Biomass Power and Cogeneration Programme. Available from: 〈http://mnre.gov.in/schemes/grid-connected/biomass-powercogen/〉; 2012 [accessed 23.10.12]

[26] Kumar A, et al. Renewable energy in India: current status and future potentials. Renewable and Sustainable Energy Reviews 2010;14(8):2434-42.

[27] MNRE. National Biomass Programme. Available from: <http://www.mnre. gov.in/prog-biomasspower.htm $>; 2011$ [accessed 20.12.11]

[28] MNRE. Biomass energy and co-generation (non-bagasse) in industry. Available from:〈http://mnre.gov.in/biomass-energyco.htm 〉; 2011 [accessed 20. 12.11].

[29] MNRE. Biogas based Distributed/Grid Power Generation Programme. Available from: 〈http://mnre.gov.in/file-manager/gridbiogas-2/biogaspower-2010-11. pdf $>; 2012$ [accessed 23.10.12]

[30] MNRE. Biomass Gasifier Program. Available from: <http://mnre.gov.in/ file-manager/grid-biomass-gasification/biomass-gasifier-2010-11.pdf $\rangle$; 2012 [accessed 23.10.12]

[31] MNRE. National Policy on Biofuels 2009.

[32] Arora DS., et al. Indian Renewable Energy Status Report. NREL 2010.

[33] MNRE. Strategic plan for new and renewable energy sector for the period 2011-2017; 2011.

[34] KNRT. Buku Putih Penelitian, Pengembangan dan Penerapan Ilmu Pengetahuan dan Teknologi Bidang Sumber Energi Baru dan Terbarukan untuk Mendukung Keamanan Ketersediaan Energi Tahun 2025. KNRT (Ministry of Research and Technology). Jakarta 2006.

[35] Hasan MH, Mahlia TMI, Nur H. A review on energy scenario and sustainable energy in Indonesia. Renewable and Sustainable Energy Reviews 2012;16(4):2316-28.

[36] IEA. Biomass gasification in Indonesia 2006

[37] ESDM. Siaran Pers: Indo-bioenergy 2011. Available from: <http://www. esdm.go.id/siaran-pers/55-siaran-pers/4528-indo-bioenergy-2011.html $\rangle$; 2011 [accessed 27.12.11]
[38] Jayed MH, et al. Prospects of dedicated biodiesel engine vehicles in Malaysia and Indonesia. Renewable and Sustainable Energy Reviews 2011;15(1): 220-35.

[39] Raj NT, Iniyan S, Goic R. A review of renewable energy based cogeneration technologies. Renewable and Sustainable Energy Reviews 2011;15(8): 3640-8.

[40] Buragohain B, Mahanta P, Moholkar VS. Biomass gasification for decentralized power generation: the Indian perspective. Renewable and Sustainable Energy Reviews 2010;14(1):73-92.

[41] MNRE. Strategy on R\&D activities for thermo-chemical conversion and promotion of biomass energy in the country, I. In: MNRE, editor. 2011.

[42] Kirubakaran V, et al. A review on gasification of biomass. Renewable and Sustainable Energy Reviews 2009;13(1):179-86.

[43] GOI. Year end review 2011. Press Information Bureau, Government of India; 2011.

[44] MNRE. Cumulative deployment of various renewable energy systems/devices in the country as on 31/08/2012. Available from: <http://mnre.gov.in/ mission-and-vision-2/achievements/ $\rangle ; 2012$ [accessed 23.10.12].

[45] MNRE. Key Statistics. Available from:〈http://www.mnre.gov.in/〉; 2011 [accessed 20.12.11].

[46] GAIN. India Biofuels Annual 2011. USDA: Global Agricultural Information Network 2011.

[47] Lima MGB. An institutional analysis of biofuels policies and their social implications: lessons from Brazil, India and Indonesia. UNRISD: Friedrich Ebert Stiftung 2012.

[48] MNRE. SSS-NIRE Bioenergy Promotion Fellowship Programme 2011; 2011.

[49] MNRE. HRD Policy of the Ministry. Available from: 〈http://mnre.gov.in/ schemes/human-resource-development/ $>; 2012$ [accessed 23.10.12].

[50] PREGA. Utilization of biomass waste of wood-based industry in Indonesia. PREGA 2006.

[51] ADB. Clean technology fund investment plan for Indonesia. Asian Development Bank 2010

[52] BPPT. Ageny for the Assessment and Application of Techology Indonesia. Available from:〈http://www.bppt.go.id/en/ >; 2011 [accessed 27.12.11].

[53] Boedoyo MS, Sugiyono A. Decentralized power generation in Indonesia: current issues and prospects. Tech Monitor 2010;May-Jun 2010.

[54] ICAERD. Indonesian Center for Agricultural Engineering Research and Development. Available from: 〈http://mekanisasi.litbang.deptan.go.id/eng/〉; 2011 [accessed 27.12.11].

[55] Widodo TW, Rahmarestia E. Current status of bioenergy development in Indonesia. In: Proceedings of the Regional Forum on Bioenergy Sector Development: challenges, opportunities and the way forward. Bangkok; 2008.

[56] Hadiwidjoyo S. Indonesia's Biofuels Policies and Program: ESDM. Biomass Asia Workshop 2009.

[57] ITA. Renewable Energy Market Assessment Report: Indonesia. U.S. Department of Commerce: International Trade Association 2010.

[58] KLH. Bioenergy: opportunity, challenge, and way forward in Indonesia 2009.

[59] GAIN. Indonesia Biofuels Annual 2011. USDA: Global Agricultural Information Network 2011.

[60] ESDM. 2011, Realisasi Pemanfaatan BBN Meningkat. Available from: <http:// www.ebtke.esdm.go.id/energi/energi-terbarukan/bioenergi/457-2011-realisa si-pemanfaatan-bbn-meningkat.html $>; 2012$ [accessed 30.01.12].

[61] CASINDO. Capacity development and strengthening for energy policy formulation and implementation of sustainable energy projects in Indonesia. Available from:〈http://www.casindo.info >; 2009 [accessed 20.02.12].

[62] CASINDO. 5th TWG VI meeting. 13th July 2011. Available from: <http:// www.casindo.info/twg-meetings/twg-vi/ >; 2011 [accessed 23.10.12]. 